\title{
Constitutive Expression of hrap Gene in Transgenic Tobacco Plant Enhances Resistance Against Virulent Bacterial Pathogens by Induction of a Hypersensitive Response
}

\author{
Mang-jye Ger, ${ }^{1}$ Cheng-hsien Chen, ${ }^{2}$ Shaw-yhi Hwang, ${ }^{2}$ Hsiang-en Huang, ${ }^{3}$ Appa Rao Podile, ${ }^{2,4}$ Badri \\ Venkata Dayakar, ${ }^{2}$ and Teng-yung Feng ${ }^{1,2}$ \\ ${ }^{1}$ Graduate Institute of Life Sciences, National Defense Medical Center, Taipei, Taiwan, Republic of China; ${ }^{2}$ Institute of \\ Botany, Academia Sinica, Taipei, 115, Taiwan, Republic of China; ${ }^{3}$ Institute of Pathology, National Taiwan University, \\ Taipei, 115, Taiwan, Republic of China; ${ }^{4}$ Department of Plant Science, University of Hyderabad, Hyderabad-500 046, India
}

Submitted 8 February 2002. Accepted 8 April 2002.

\begin{abstract}
Hypersensitive response-assisting protein (HRAP) has been previously reported as an amphipathic plant protein isolated from sweet pepper that intensifies the harpin ${ }_{\mathrm{Pss}}-\mathrm{medi}$ ated hypersensitive response (HR). The hrap gene has no appreciable similarity to any other known sequences, and its activity can be rapidly induced by incompatible pathogen infection. To assess the function of the hrap gene in plant disease resistance, the CaMV 35S promoter was used to express sweet pepper hrap in transgenic tobacco. Compared with wild-type tobacco, transgenic tobacco plants exhibit more sensitivity to harpin ${ }_{P s s}$ and show resistance to virulent pathogens (Pseudomonas syringae pv. tabaci and Erwinia carotovora subsp. carotovora). This disease resistance of transgenic tobacco does not originate from a constitutive HR, because endogenous level of salicylic acid and hsr203J mRNA showed similarities in transgenic and wildtype tobacco under noninfected conditions. However, following a virulent pathogen infection in hrap transgenic tobacco, hsr203J was rapidly induced and a micro-HR necrosis was visualized by trypan blue staining in the infiltration area. Consequently, we suggest that the disease resistance of transgenic plants may result from the induction of a HR by a virulent pathogen infection.
\end{abstract}

Various defense responses are induced when a pathogen attempts to invade a nonhost plant or resistant host. Among these induced responses, hypersensitive response (HR), the most distinguished hallmark of resistance, is characterized by a rapid, localized plant cell death at the site of infection (Dangl et al. 1996; Goodman and Novacky 1994; Lamb and Dixon 1997). The HR generates a physical barrier composed of dead plant cells and limits the availability of nutrients to the pathogen, which can further restrict its spread. Other defense-related responses often accompany $\mathrm{HR}$, such as oxidative burst (Sutherland 1991), the production of antimicrobial compounds (Dangl 1994) and enzymes involved in the general phenylpropanoid pathway (Dixon and Lamb 1990; Hahlbrock and Scheel 1989). HR also induces many defense-related signal molecules, such as salicylic acid (SA), ethylene, and jasmonic acid

Corresponding author: T.-Y. Feng; Institute of Botany, Academia Sinica; E-mail: bofeng@gate.sinica.edu.tw; Telephone: +886-2-26521867; Fax: +886-2-2782-7954.
(Malamy et al. 1990; Penninckx et al. 1996). Recent reports suggest SA has emerged as a key signal in the establishment of systemic acquired resistance (SAR), able to protect the plant against further pathogen invasion (Delaney et al. 1994; Gaffney et al. 1993). Exploitation of the characteristics of HR or SAR as a useful strategy to increase plant disease resistance has been reported (Blaszczyk et al. 1999; Epple et al. 1997; Keller et al. 1999; Shen et al. 2000; Verberne et al. 2000).

The ability of some gram-negative bacterial pathogens, such as Pseudomonas, Xanthomonas and Erwinia strains, to cause disease in susceptible plants and elicit HR in resistant plants, is governed by the hrp (HR and pathogenicity) gene cluster (Bonas 1994), also known as hrp-hrc (HR-conserved) (Bogdanove et al. 1996). These genes encode components of a novel protein secretion pathway designated as a type III secretion system (Van Gijsegem et al. 1993). The pathway is used to deliver proteins from the bacterial cytoplasm either to the culture medium or into the host cell cytoplasm (Galán and Collmer 1999). Mutations in hrp genes result in the elimination of the bacterium's ability to cause disease in susceptible plants and to trigger resistance in resistant plants (Huang et al. 1988, 1995). The Hrp ${ }^{-}$phenotype is thought to be a result of the failure of mutants to deliver proteinaceous effectors to the plant cell cytoplasm (Alfano and Collmer 1997; Grant and Mansfield 1999; Tsiamis et al. 2000). This suggests that proteins traversing the type III secretion system may be involved in the establishment of an early stage of interaction between plant and pathogen.

Harpins, a group of effector proteins exported by the type III pathway of plant pathogenic Erwinia, Pseudomonas, and Ralstonia spp., are able to trigger HR in the absence of other bacterial proteins (Galán and Collmer 1999). The pathogenicity of Erwinia amylovora was significantly reduced when harpin ${ }_{\mathrm{Ea}}$ was mutated (Bauer et al. 1995; Wei et al. 1992). However, mutations in harpin ${ }_{\text {Pst }}$ apparently did not affect the virulence of P. syringae pv. tomato (Charkowski et al. 1998). More recently, evidence has suggested that harpin ${ }_{\mathrm{Pss}}$-treated Arabidopsis thaliana suspension cell cultures are able to induce the rapid generation of $\mathrm{H}_{2} \mathrm{O}_{2}$ (Desikan et al. 1996) and mitogen-activated protein kinase activity during defense responses (Desikan et al. 1999). Tampakaki and Panopoulos (2000) reported that harpin endogenously expressed in tobacco causes HR only when it is produced in a secretable form. This finding suggests that one or more plant cellular receptors for harpin are extracellular. In vitro immunogold labeling also found harpin associated with 
the pilus (Brown et al. 2001). Moreover, it was shown that harpin could bind to lipid bilayers and could form an ion-conducting pore in vitro that may serve to facilitate the delivery of virulent factors into host plant cells using the type III secretion/translocation machinery (Lee et al. 2001). However, the role of harpins during colonization of host plants and their site of action remains elusive.

Previously, a cationic protein from sweet pepper, hypersensitive response-assisting protein (HRAP), was found to be able to intensify the harpin ${ }_{\mathrm{Pss}}-$ mediated HR in harpin $_{\mathrm{Pss}}$-insensitive plants (Chen et al. 1998). HRAP could dissociate harpin ${ }_{\text {Pss }}$ multimeric forms into dimeric and monomeric forms that could trigger a stronger HR necrosis in sweet pepper. The hrap gene is widely distributed throughout a broad range of plant species, including tobacco, Arabidopsis, and rice. However, it has no appreciable similarity to any known sequences. Sequence comparisons of HRAP showed it to contain a typical signal peptide leading to secretion into extracellular matrices. Additionally, the transcriptional activity of the hrap gene was induced early during the incompatible interaction of sweet pepper with $P$. syringae (Chen et al. 2000). Based on these results, it is possible that HRAP is closely involved in the plant defense mechanism. In order to assess the merits of HRAP regarding plant disease resistance, we developed transgenic tobacco plants, using the sweet pepper hrap gene that is under the control of the Cauliflower mosaic virus (CaMV) $35 \mathrm{~S}$ promoter. In this investigation, we report that constitutive expression of the hrap gene in transgenic tobacco plants increases their sensitivity to harpin ${ }_{\mathrm{Pss}}$ and shows host resistance to virulent bacterial pathogens. An alternative strategy for generating plant disease resistance through the induction of a HR under the conditions of a compatible interaction is described below.

\section{RESULTS}

Screening and expression analysis of hrap transgenic tobacco plants.

Tobacco plants expressing the hrap gene of sweet pepper were generated using Agrobacterium-mediated transformation. The sweet pepper hrap cDNA constructed for transformation was designated pS-hrap (Fig. 1). Agrobacterium-mediated transformation yielded six viable transformed lines designated S-hrap, selected using kanamycin at the rate of $100 \mu \mathrm{g} / \mathrm{ml}$. Individual T1 plants from each line were selffertilized, and seeds were collected. Individual T2 progeny were selected and were further screened using polymerase chain reaction (PCR) to detect the presence of transformed hrap gene. Only positive transformants were selected for further analysis. Western blot analysis showed that HRAP protein expression levels do not exhibit significant differences between the T2 transgenic lines. It was also observed that plant morphology is similar to that of wild-type tobacco (data not shown).

Two lines, S-hrap3 and S-hrap6, were selected for further examination. In order to identify distribution and the copy number of the hrap transgene in transgenic tobacco genomes, genomic DNA was extracted from the transgenic lines and subjected to Southern blot analysis. Given that wild-type tobacco contains the hrap gene (Chen et al. 2000), neomycin phosphotransgerase II (NPT II) cDNA was used as a probe to identify the transgene loci. Genomic DNA was digested from both S-hrap3 and S-hrap6 with either the EcoRI or SacI restriction enzyme. Figure $2 \mathrm{~A}$ shows that, after probing with the NPT II cDNA probe, two bands $(5.2 \mathrm{~kb}$ and $4.3 \mathrm{~kb})$ are detected in the EcoRI-digested lane and one band $(6.2 \mathrm{~kb})$ in the SacI-digested lane of S-hrap3 genomic DNA. The banding pattern detected in the S-hrap6 transgenic tobacco exhibits a $6.8-\mathrm{kb}$ band in the EcoRI-digested lane and a $5.5-\mathrm{kb}$ band in the SacI-digested lane. The different patterns suggest that S-hrap3 and S-hrap6 result from independent transformation events and incorporate the hrap transgene at different chromosomal locations.

Two transgenic lines were subjected to Northern blot analysis to detect hrap gene expression levels, using hrap cDNA as a probe. It was found that the hrap transgene was expressed in two transgenic lines and that there is no signal in wild-type tobacco (Fig. 2B). Western blot analysis showed the HRAP protein to be constitutively expressed in both transgenic lines, whereas it was barely detectable in wild-type tobacco (Fig. 2C). The above results indicate that the expression activities of hrap transgene, both the transcription and the translation levels, do not significantly differ in both transgenic lines, even though Shrap3 has two copies of the hrap transgene.

hrap Transgenic plants show a high sensitivity to harpin ${ }_{\text {Pss }}$.

In previous studies, we reported that HRAP could intensify the harpin $_{\mathrm{Pss}}$-mediated HR in the intercellular spaces of sweet pepper leaves (Chen et al. 1998). In order to confirm this phenomenon and to investigate the relationship between the HRAP protein and harpin $_{\text {Pss }}$-mediated HR in vivo, two different quantities of harpin $_{\text {Pss }}$ were infiltrated into intercellular spaces of transgenic and wild-type tobacco leaves, and HR necrosis were subsequently observed. After infiltration with $10 \mu \mathrm{g}$ harpin Pss $_{\text {over a }}$ period of $24 \mathrm{~h}$, the transgenic tobacco leaves showed a HR necrosis almost to the full extent of the infiltration area, but the wild-type tobacco leaves exhibited a weaker HR necrosis. Even infiltration using lower concentrations of harpin ${ }_{\text {Pss }}(5 \mu \mathrm{g})$ over a period of $24 \mathrm{~h}$ in the transgenic line leaves showed more than a $60 \%$ HR necrosis of the infiltration area (Fig. 3). Thus, the quantity of harpin ${ }_{\mathrm{Pss}}$ causing a limited HR necrosis in wild-type tobacco causes more serious necrosis in hrap transgenic plants. This phenomenon was confirmed in triplicate from three individual plants each of transgenic and wild-type tobacco. These results suggest that HRAP influences harpin ${ }_{\text {Pss }}-$ mediated HR in vivo and increases plant sensitivity to harpin ${ }_{\mathrm{Pss}}$.

\section{hrap Transgenic tobacco exhibited resistance to virulent bacterial pathogens.}

To determine the merit of the hrap gene regarding plant disease resistance, two transgenic lines were challenged with the virulent pathogens $P$. syringae pv. tabaci and E. carotovora subsp. carotovora. Six individual tobacco plants from two

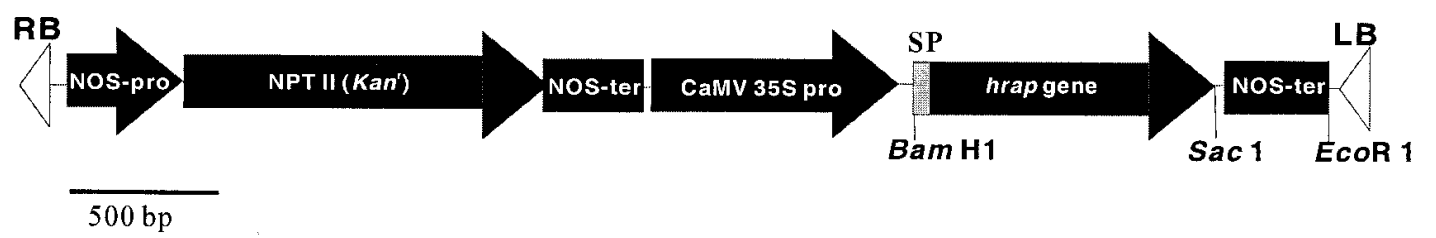

Fig. 1. Map of the relevant portions of the transformation plasmid pS-hrap. NOS-pro = the promoter region of Agrobacterium tumefaciens nopalin synthase gene, NOS-ter $=$ the terminator region of the same gene, NPTII $=$ the coding sequence of the neomycin phosphotransferase II gene, CaMV $35 \mathrm{~S}$-pro $=$ the CaMV 35S promoter sequence, hrap = the coding sequence for the sweet pepper HRAP, and SP = signal peptide of sweet pepper HRAP. 
transgenic lines and wild-type plants were inoculated with $P$. syringae pv. tabaci $\left(1.0 \times 10^{7} \mathrm{CFU} / \mathrm{ml}\right)$. Three days after inoculation, wild-type tobacco leaves exhibited yellowing symptoms, later turning brown and eventually black after prolonged incubation for eight days (Fig. 4A). However, the leaves of transgenic lines remained healthy and free from disease symptoms. Bacterial populations in the infiltration areas were calculated postinoculation on different days. Two days postinoculation, the population of $P$. syringae pv. tabaci in the transgenic lines was reduced significantly compared with the wild-type tobacco $(P<0.05)$ (Fig. 4A, graph). Six days post-inoculation, the population of $P$. syringae pv. tabaci in both transgenic lines was approximately $16 \%$ of that found in the wild-type tobacco. This result suggests that proliferation of $P$. syringae pv. tabaci was significantly inhibited in the leaf tissue of both transgenic lines. Transgenic plants were also evaluated for resistance to bacterial soft rot disease caused by E. carotovora subsp. carotovora. A low concentration of E. carotovora subsp. carotovora $\left(1.0 \times 10^{6} \mathrm{CFU} / \mathrm{ml}\right)$ was infiltrated into tobacco leaves for the resistance assay, because higher concentrations cause tissue maceration in wild-type tobacco leaves, influencing detection of bacterial numbers. As shown in Figure 4B, 3-days-postinoculation transgenic tobacco leaves showed no symptoms and remained healthy, while wild-type tobacco leaves exhibited water-soak symptoms and tissue maceration caused by the bacterial infection. The population of E. carotovora subsp. carotovora in the infiltration area was determined at different times postinoculation. A $t$ test demonstrated that differences in pathogen number between transgenic and wild-type tobacco 2 days postinfection were significant $(P<0.05)$. Postinoculation (4 days), the population of E. carotovora subsp. carotovora in the wild-type tobacco was approximately six times higher than that found in the transgenic lines (Fig. 4B, graph). This result indicates that constitutive expression of hrap in tobacco could inhibit $E$. carotovora subsp. carotovora proliferation. In addition, an absorption assay was performed to test for disease resistance, because E. carotovora subsp. carotovora is known to spread through the plant's venous system in nature. Fully expanded detached leaves from two-month-old plants were placed in beakers containing a $10-\mathrm{ml}$ suspension of E. caroto-
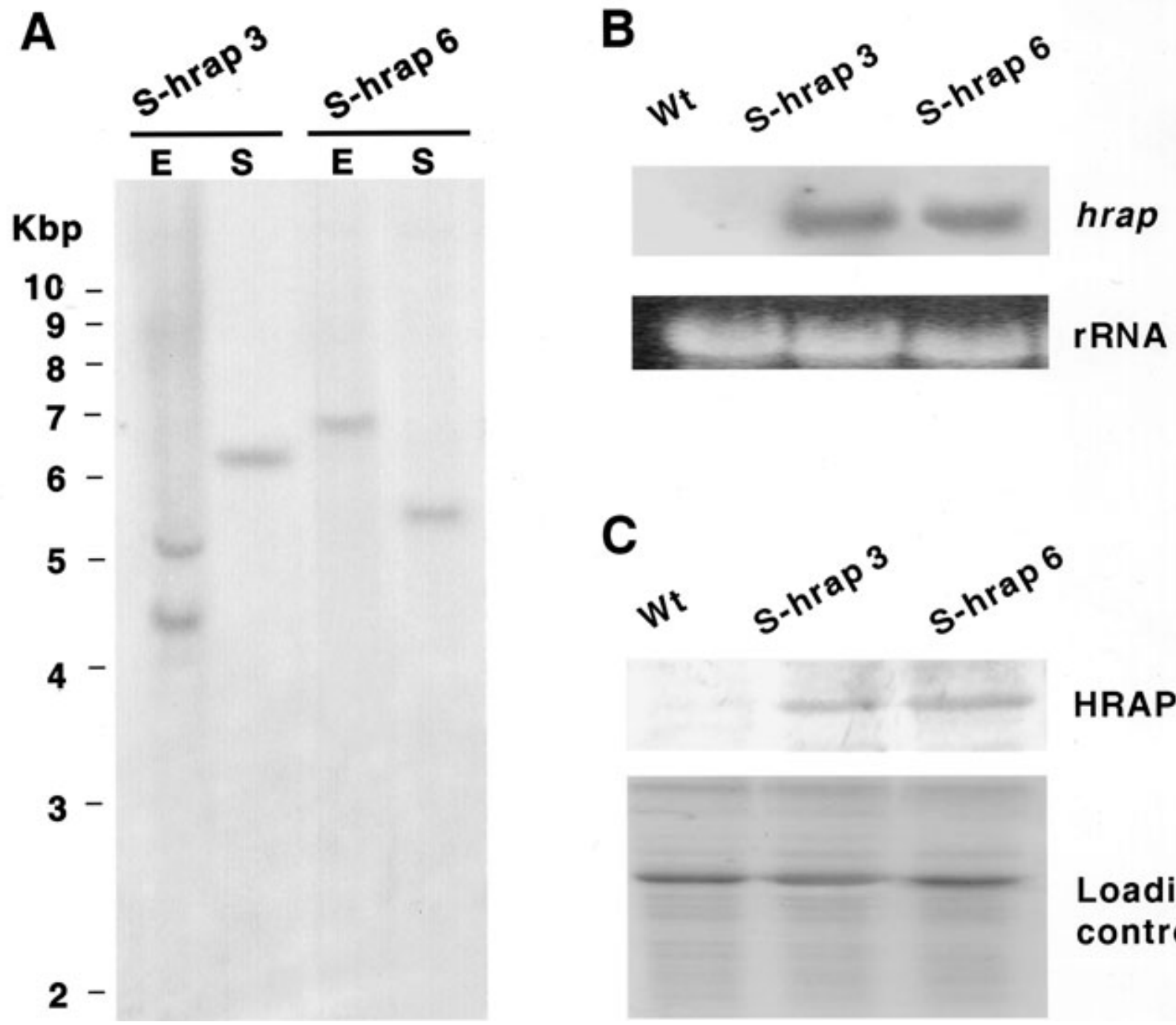

HRAP

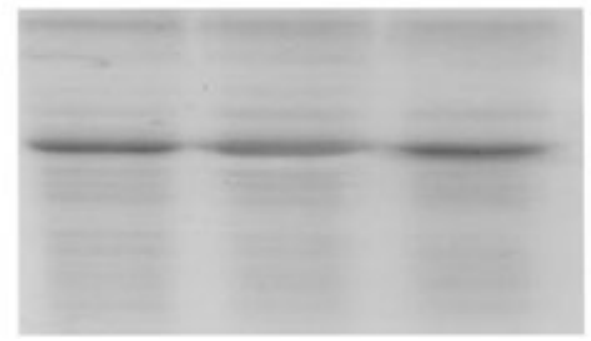

\section{Loading control}

Fig. 2. Gel blot analysis of genomic DNA and hrap expression in transgenic plants. A, DNA gel blot analysis of S-hrap3 and S-hrap6 transformed tobacco using NPTII cDNA as the probe. Genomic DNA $(15 \mu \mathrm{g}$ ) was digested with either EcoRI (lane E) or SacI (lane S) for both S-hrap3 and S-hrap6 as indicated and then subjected to Southern blot analysis. B, RNA gel blot analysis of T2 progeny of S-hrap3 and S-hrap6 transgenic plants as well as of that of an untransformed control plant (Wt). Total RNA $(15 \mu \mathrm{g})$ was loaded on each of the lanes and hybridized to a DIG-labeled hrap cDNA probe. Ethidium bromide staining of rRNA was used to verify the loaded amount of total RNA. C, Protein gel blot analysis of S-hrap3, S-hrap6, and control (Wt) plants. Total protein $(20 \mu \mathrm{g})$ from T2 progeny of S-hrap3, S-hrap6 transgenic plants, and control tobacco leaves was purified and subjected to gel blot analysis for protein. The blot was hybridized with anti-HRAP antibody able to detect amounts of HRAP down to $0.1 \mathrm{ng}$. Coomassie blue staining of total protein was used to verify the loading amount. 
vora subsp. carotovora $\left(1.0 \times 10^{7} \mathrm{CFU} / \mathrm{ml}\right)$ and were incubated in a chamber at $28^{\circ}$ for $24 \mathrm{~h}$. Figure $4 \mathrm{C}$ shows that water-soak symptoms of leaves from transgenic lines seem limited to the main vein, while leaves from wild-type plants exhibited watersoak symptoms, maceration, and rotten regions around the veins. This result suggests that transgenic plants may resist the spread of E. carotovora subsp. carotovora through the plant's venous system. Based on these results, we suggest that constitutive expression of the hrap gene in transgenic tobacco enhances resistance against two kinds of virulent pathogens, $P$. syringae pv. tabaci and E. carotovora subsp. carotovora.

\section{Exogenous HRAP inhibits pathogen proliferation}

in the intercellular spaces of tobacco leaves but not in vitro.

To determine whether HRAP contains antibacterial activity, an antibacterial assay was performed. $P$. syringae pv. tabaci bacterial suspensions $\left(1.0 \times 10^{7} \mathrm{CFU} / \mathrm{ml}\right)$ were inoculated with Escherichia coli-expressed recombinant HRAP protein or control protein (bovine serum albumin [BSA]) at $30^{\circ}$ for $48 \mathrm{~h}$. Recombinant HRAP was determined to have no direct toxicity to $P$. syringae pv. tabaci at the concentration of $1 \mu \mathrm{M}$ or even at a threefold higher concentration (data not shown). However, 1 $\mu \mathrm{M}$ of recombinant HRAP could inhibit $P$. syringae pv. tabaci proliferation in the intercellular spaces of tobacco leaves. $P$. $s y$ ringae pv. tabaci suspensions $\left(1.0 \times 10^{7} \mathrm{CFU} / \mathrm{ml}\right)$ mixed with recombinant HRAP $(1 \mu \mathrm{M})$ expressed by Escherichia coli were infiltrated into the intercellular spaces of wild-type tobacco leaves. The tobacco leaves infiltrated with $P$. syringae pv. tabaci and control protein showed conventional disease symptoms 6 days postinoculation; however, no symptom was evident in the leaves coinfiltrated with $P$. syringae pv. tabaci and the recombinant HRAP (Fig. 5A). The effect of the recombinant HRAP protein on bacterial proliferation was also studied. The bacterial population initially mixed with the recombinant HRAP (5 days post-inoculation) was approximately $20 \%$ of the population of the control (Fig. 5B). This result suggests that proliferation of $P$. syringae pv. tabaci was significantly inhibited by recombinant HRAP in the intercellular space of leaves tissue $(P<0.05)$. Accordingly, we suggest that recombinant HRAP protein can inhibit $P$. syringae pv. tabaci proliferation and reduce disease symptoms in tobacco leaves through an indirect mechanism.

\section{Total salicylic acid basal levels are not influenced} by constitutive expression of hrap in transgenic tobacco.

In plants, SA appears to be an essential part of the pathway leading to SAR in which a general correlation between SA levels and disease resistance was noted (Morris et al. 1998). It was reported that overproduction and accumulation of SA in transgenic plants resulted in constitutive expression of defense genes and in enhanced disease resistance against various pathogens (Verberne et al. 2000). In order to determine if the constitutive expression of hrap in transgenic tobacco influences the endogenous level of SA leading to the induction of SAR and increased disease resistance, the SA levels in two transgenic tobacco lines were compared with control plants. Figure 6 demonstrates that the basal levels of free and conjugate SA show no statistical difference between the wild-type and transgenic plants. This result suggests that constitutive expression of hrap in transgenic plants does not influence SA accumulation at the basal level.

\section{A micro-HR is induced in transgenic tobacco by a virulent pathogen.}

HRAP was previously found to influence harpin ${ }_{\mathrm{Pss}}-$ mediated HR and to be induced in incompatible interaction in sweet pepper and, thus, may be involved in the HR process (Chen et al.
1998, 2000). In order to reveal whether the disease resistance of transgenic plants involves the HR mechanism, HR molecular marker $h s r 203 J$ was utilized. $h s r 203 J$ has recently been studied and its physiological function was found to be potentially involved in the early processes of HR (Pontier et al. 1994, 2001). It has been established that hsr203J transcripts accumulate specifically in tissues undergoing HR following pathogen infection or harpin infiltration into leaf intercellular spaces (Pontier et al. 1994, 2001). Under noninfected conditions, $h s r 203 J$ was inactive in transgenic and wild-type tobacco (Fig. 7A), indicating that constitutive expression of hrap in transgenic plants does not trigger hsr203J expression. The expression of $h s r 203 J$ was also monitored in transgenic and wildtype tobacco during a virulent pathogen infection. Total RNA was extracted from transgenic and wild-type tobacco leaves and was hybridized with the hsr203J probe after inoculation with the virulent pathogen $P$. syringae pv. tabaci. During the inoculation treatment, the $h s r 203 J$ gene was induced in the early stages at $4 \mathrm{~h}$ and reached a maximum level $24 \mathrm{~h}$ postinoculation in transgenic tobacco. However, hsr203J mRNA was undetectable within $24 \mathrm{~h}$ postinoculation in wildtype tobacco (Fig. 7A). Additionally, the trypan blue-staining method, which selectively stains dead or dying cells, was used to detect a micro-HR development in transgenic and wild-type tobacco after virulent pathogen infection. The micro-HR was visible as an expanded region of blue-stained cells in the infiltration area of transgenic tobacco leaves infected with $P$. syringae pv. tabaci. However, no region of blue-stained cells was observed in the infiltration area of wild-type tobacco leaves after infection (Fig. 7B). Based on these results, we suggest that the disease resistance of hrap transgenic tobacco plants results from the triggering of a micro-HR to protect themselves from pathogen attack.

\section{DISCUSSION}

Genetic engineering has proven to be a powerful tool in modifying plant disease resistance and to be an alternative to undesirable chemical control. Different genetic strategies have been proposed to engineer plant resistance to bacterial disease, including producing antibacterial proteins of nonplant origin, enhancing natural plant defenses, and artificially inducing programmed cell death at the site of infection (Blaszczyk et al.

\section{S-hrap 3}

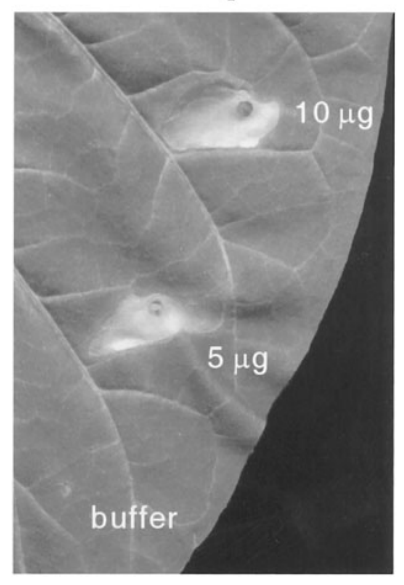

Wt

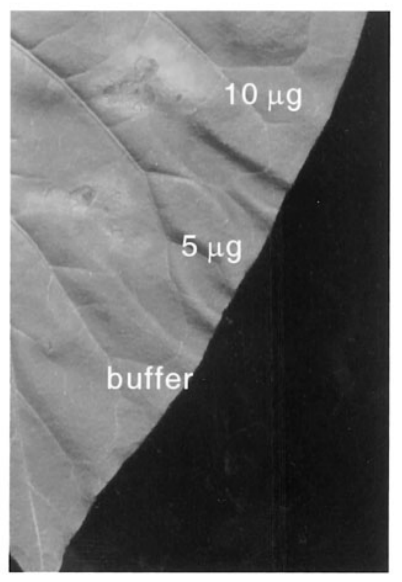

Fig. 3. The harpin ${ }_{\mathrm{Pss}}-$ mediated hypersensitive response (HR) test in transgenic and wild-type tobacco leaves. Harpin ${ }_{\text {Pss }}(10$ and $5 \mu \mathrm{g}$ ) was infiltrated into transgenic (S-hrap3) and wild-type tobacco leaves (Wt), respectively. The buffer alone was used as the control. HR necrosis was observed after $24 \mathrm{~h}$ and photographed 4 days postinoculation. 
A

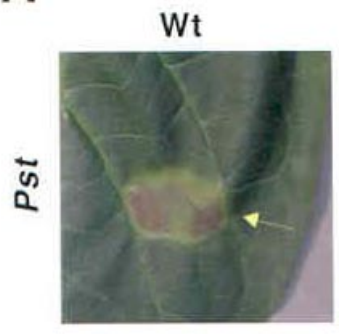

\section{S-hrap 3}
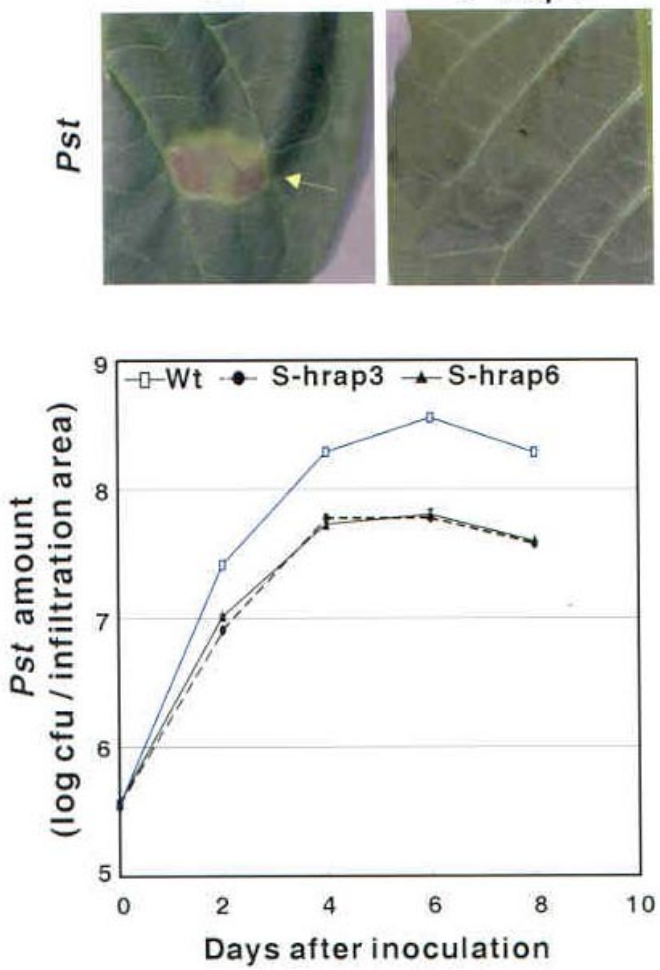

C

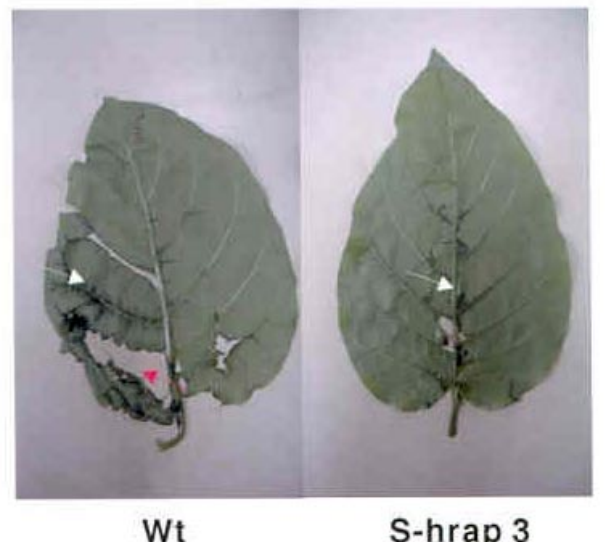

S-hrap 3
B
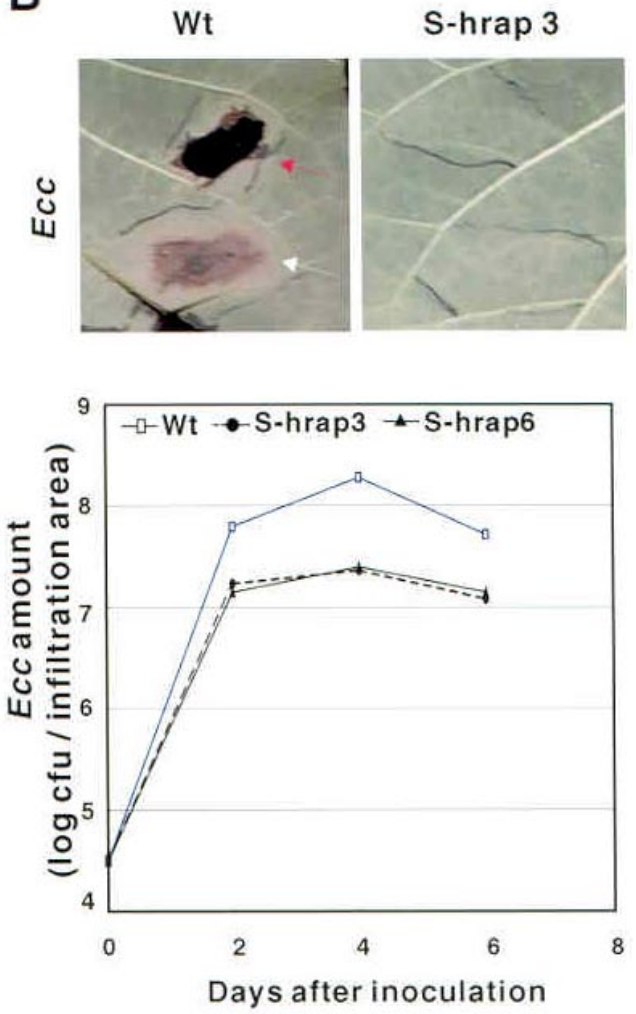

Fig. 4. Resistance of hrap transgenic tobacco to virulent pathogens, Pseudomonas syringae pv. tabaci and Erwinia carotovora subsp. carotovora. A, Enhanced resistance against $P$. syringae pv. tabaci in transgenic tobacco leaves. Fully expanded upper leaves of transgenic (S-hrap3) and control tobacco (Wt) were infiltrated with $40 \mu \mathrm{l}$ of bacterial suspension of $P$. syringae pv. tabaci $\left(1.0 \times 10^{7} \mathrm{CFU} / \mathrm{ml}\right.$, denoted Pst $)$ for wild fire disease and were incubated in a humidifying chamber. Photographs were taken 8 days after inoculation. Yellow arrows indicate disease symptoms of wild fire disease. The bottom graph shows growth inhibition of $P$. syringae pv. tabaci i in the leaves of S-hrap3 and S-hrap6 transgenic plants. Six leaves from individual transgenic plants in each of the lines and from wild-type tobacco were infiltrated with $40 \mu \mathrm{l}$ of P. syringae pv. tabaci $\left(1.0 \times 10^{7} \mathrm{CFU} / \mathrm{ml}\right)$. Bacterial populations were detected within the full infiltrated areas in transgenic lines (S-hrap3 and S-hrap6) and wild type-plants (Wt) on successive days postinoculation. B, Enhanced resistance against E. carotovora subsp. carotovora in transgenic tobacco leaves. Fully expanded upper leaves of the control (Wt) and of transgenic tobacco (S-hrap3) were infiltrated with $40 \mu \mathrm{l}$ of bacterial suspension of E. carotovora subsp. carotovora $\left(1.0 \times 10^{6} \mathrm{CFU} / \mathrm{ml}\right.$, denoted Ecc) for soft rot disease and were incubated in a humidifying chamber. Photographs were taken 3 days after inoculation. White arrows indicate water-soak symptoms of soft rot disease, while red arrows indicate rotten tissue caused by it. The bottom graph shows growth inhibition of E. carotovora subsp. carotovora in the leaves of S-hrap3 and S-hrap6 transgenic plants. Six leaves from individual transgenic plants in each of the lines and from wild-type tobacco were infiltrated with $40 \mu \mathrm{l}$ of E. carotovora subsp. carotovora $\left(1.0 \times 10^{6} \mathrm{CFU} / \mathrm{ml}\right)$. Bacterial numbers were estimated within the full infiltration areas in transgenic lines (S-hrap3 and S-hrap6) and in wild-type (Wt) plants on successive days postinoculation. C, Enhanced resistance against E. carotovora subsp. carotovora in the hrap transgenic line was demonstrated using an absorption inoculation method. Fully expanded leaves of S-hrap3 transgenic tobacco and wildtype plants were detached and soaked in a beaker containing a $10 \mathrm{ml}$ suspension of E. carotovora subsp. carotovora $\left(1.0 \times 10^{7} \mathrm{CFU} / \mathrm{ml}\right)$ and were incubated in a chamber at $28^{\circ} \mathrm{C}$ for $24 \mathrm{~h}$ and subsequently photographed. White arrows point to water-soak symptoms of soft rot disease, while red arrows point to rotten tissue caused by it. Error bars indicate standard deviation of the mean of six individual plants for each line. 
1999; Epple et al. 1997; Keller et al. 1999; Shen et al. 2000; Verberne et al. 2000). A sweet pepper protein, HRAP, has been shown to influence harpin Pss - mediated HR (Chen et al. 1998). The cDNA of HRAP shows no appreciable similarity to any processes (Chen et al. 2000). In this report, we demonstrate known sequences, and its expression level correlated with HR that the constitutive expression of a sweet pepper hrap gene in transgenic tobacco increases plant sensitivity to harpin ${ }_{P s s}$ and enhances disease resistance.

Constitutive expression of the hrap gene in tobacco plant results in enhanced disease resistance to $P$. syringae pv. tabaci and E. carotovora subsp. carotovora, further suggesting that HRAP contributes to defense against virulent pathogens. In two individual transgenic lines, the growth of $P$. syringae pv. tabaci and $E$. carotovora subsp. carotovora was significantly inhibited $(\mathrm{P}<$ 0.05) compared with growth in wild-type tobacco. Under this situation, both transgenic tobacco lines showed no visible disease symptoms after pathogen infection (Fig. 4A and 4B). We found that the hrap transgene was constitutively expressed in each transgenic tobacco line (Fig. 2B). Additionally, Southern blot analysis shows that the hrap transgene incorporated at different loci in two independent transgenic lines (Fig. 2A). This implies that disease resistance to the compatible pathogen is due to hrap transgene expression and does not result from rearrangement of the transgene at the specific locus of integration.

Engineered plant protection is usually achieved using antimicrobial peptides to inhibit pathogen growth (Epple et al. 1997; Rao 1995; Terras et al. 1995). Some toxic proteins, such as sarcotoxin IA, chitinases, defensins, and thionin, have been found to directly attack invading pathogens and insects (Mitsuhara et al. 2000; Van Loon 1999). Sequence comparison of HRAP showed that it has no appreciable conserved domain to any known toxic protein. However, the possibility that the disease resistance of hrap transgenic tobacco is due to a novel antimicrobial activity of HRAP cannot be ruled out. It was found that $1 \mu \mathrm{M}$ of recombinant HRAP protein significantly inhibited $P$. syringae pv. tabaci proliferation in the intercellular spaces of tobacco leaves
(Fig. 5B). The same concentration of recombinant HRAP, however, produced no apparent inhibition on pathogen growth in vitro, even when the concentration of recombinant HRAP was increased threefold (data not shown). Therefore, HRAP is unlikely to behave via an antimicrobial activity, but rather may act through an indirect mechanism inhibiting pathogen growth in the intercellular spaces of tobacco leaves.

Exploitation of plant endogenous defense mechanism is a useful strategy to create disease resistance traits. HR is an important defense response preventing further multiplication and restricting the spread of the pathogen in plant tissue. Previously, HRAP was found to influence harpin ${ }_{\mathrm{Pss}}$-mediated HR and to be induced in incompatible interaction in sweet pepper (Chen et al. 1998, 2000). This data suggests that HRAP may be involved in HR processes. In HR processes, HR marker gene $h s r 203 J$ has been shown to be expressed specifically and rapidly and to be highly induced during an incompatible interaction (Pontier et al. 1994). Our results show that in hrap transgenic tobacco, but not in wild type, hsr203J is induced in the early stages following a virulent pathogen infection (Fig. 7A). A micro-HR was also observed using trypan blue staining in the infiltration area of transgenic tobacco leaves upon infection by a virulent pathogen (Fig. 7B). To our knowledge, a virulent pathogen failed to induce an effective HR in the host plant. It would seem that constitutive expression of the hrap gene in transgenic tobacco converts compatible plant-pathogen interactions into incompatible interactions. Based on these results, the mechanism of disease resistance of hrap transgenic plants may be via the triggering of an HR by virulent pathogens.

A number of reports have indicated that expression of elicitors or $a v r$ gene products in transgenic plants can trigger an HR that generates broad-spectrum resistance to virulent pathogens (Büschges et al. 1997; Dietrich et al. 1994; Greenberg et al. 1994; Shen et al. 2000). However, the formation of a HR must be tightly regulated to avoid uncontrolled cell death throughout the plant. In this context, a weak promoter has been used to constitutively express an $a v r$ gene in transgenic tobacco (Shen
A

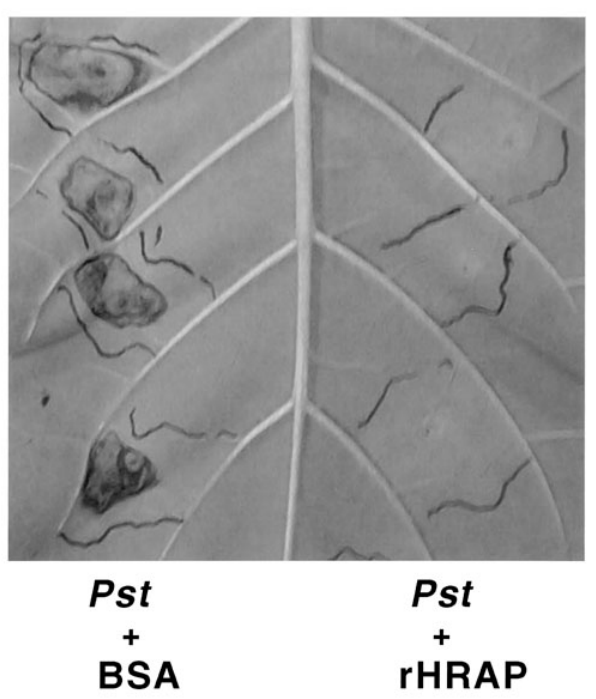

B

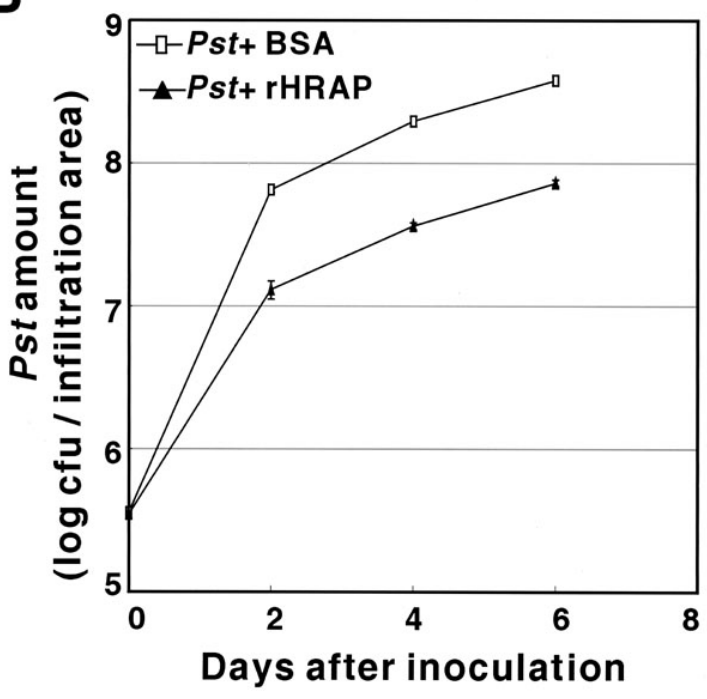

Fig. 5. Exogenous recombinant hypersensitive response-assisting protein (HRAP) inhibits Pseudomonas syringae pv. tabaci growth in the intercellular space of wild-type tobacco leaves. A, Recombinant HRAP reduced the disease symptoms caused by $P$. syringae pv. tabaci. Bacterial suspensions $(1.0 \times$ $10^{7} \mathrm{CFU} / \mathrm{ml}$ ) mixed with $1 \mu \mathrm{m}$ bovine serum albumin (BSA) (four duplicates) or recombinant HRAP (three duplicates) were infiltrated into the intercellular spaces of wild-type tobacco leaves and then incubated in a chamber at $28^{\circ} \mathrm{C}$. Disease symptoms were photographed 6 days postinoculation. B, Growth curve of $P$. syringae pv. tabaci in the presence of recombinant HRAP in the intercellular spaces of wild-type tobacco leaves. Bacterial suspension $(1.0 \times$ $10^{7} \mathrm{CFU} / \mathrm{ml}$ ) was mixed with $1 \mu \mathrm{M}$ recombinant HRAP or BSA, infiltrated into the intercellular space of wild-type tobacco leaves, and incubated in a humidifying chamber. Bacterial numbers were estimated within the full infiltrated areas on successive days postinoculation. Error bars indicate standard deviation of the mean using three individual inoculations. 
et al. 2000). This transgenic tobacco constitutively exhibits a weak HR and shows high levels of resistance against a broad range of microbial plant pathogens. The potential application of this strategy is limited, because HR is a programmed cell death process in which the plant depletes many energy resources to synthesize defense-related compounds. In nature, a $\mathrm{HR}$ is induced after the recognition of a pathogen by the plant. It is logical to construct transgenic plants to enhance disease resistance found to occur naturally. The use of an inducible HR to create disease resistance has been reported (Keller et al. 1999). In this case, a pathogen-inducible promoter was used to drive an elicitor giving rise to HR. Thus, broad-spectrum disease resistance of a plant can be generated without constitutive expression of an HR. In our studies here, we achieve the same goal without inducible expression of an elicitor, but instead by constitutive expression of hrap. Due to the constitutive expression of hrap in transgenic tobacco, neither the endogenous level of SA nor hsr203J transcript has any influence under noninfected condition (Fig. 6 and Fig. 7A), suggesting that the hrap transgene does not trigger a plant resistance response in the absence of pathogen infection. Once hrap transgenic tobacco is challenged with a virulent pathogen, it was found that a HR is induced and disease resistant features are exhibited.

The disease resistance of hrap transgenic tobacco may be related to the interaction between HRAP and harpin elicitor. Previous studies showed that the expression level of hrap was correlated with harpin ${ }_{\text {Pss }}$-mediated HR (Chen et al. 1998). We also found that hrap transgenic tobacco exhibits higher sensitivity to harpin $_{\text {Pss }}$ than wild type (Fig. 3). Additionally, Pseudomonas and Erwinia spp. have been reported to deliver harpin protein to the surface of the plant cell through a type III secretion (Galán and Collmer 1999). HRAP has a chance to interact with harpins and achieve an intensification of HR, because it contains a signal peptide leading HRAP into the extracellular matrix (Chen et al. 2000). It seems that HRAP can react with harpin elicitor to enhance harpin-mediated $\mathrm{HR}$ and plant disease resistance. If HRAP directly interacts with the harpin elicitor to trigger a HR, further HRAP biochemical analyses and harpin-deficient bacterial pathogen invasion assays warrant investigation.

\section{MATERIALS AND METHODS}

Construction of the transformation vector.

The coding sequence of hrap gene was amplified from a hrap clone (Chen et al. 2000) by PCR with the following prim- ers: BH5, 5'-CGCGGATCCATGAAAATGAAGAACCTCTC -3'; and SH3, 5'-CGAGCTCGTTAAAATAGTTGACCAAGGGTCTC $-3^{\prime}$. The PCR product was digested with BamHI and SacI and purified. The full-length hrap fragment replaced the GUS protein coding sequence from pBI121 vector (Clontech, Palo Alto, CA, U.S.A.), and the insert was verified by DNA sequencing. The resultant plasmid, pS-hrap, was then transformed into Escherichia coli $\mathrm{DH} 5 \alpha$.

\section{Generation of transgenic tobacco lines.}

Agrobacterium tumefaciens C58C1 was transformed with pS-hrap vector as described by Holsters and associates (1978). Transformants of tobacco (Nicotiana tabacum cv. Samsun NN) were obtained by the standard leaf disc transformation method using kanamycin selection (100 mg/l) (Horsch et al. 1985). Six independent transformant lines were confirmed by PCR analysis and DNA gel blotting. All transgenic plants were grown in a growth chamber $\left(16 \mathrm{~h}\right.$ light and $8 \mathrm{~h}$ dark at $\left.30^{\circ} \mathrm{C}\right)$. Six transgenic lines were selffertilized, and the seeds were collected for seeding and PCR analysis.

Extraction and gel blot analysis of DNA, RNA, and protein.

Genomic DNA was extracted from young leaf tissue by the Qiagen genomic tip protocol (Qiagen, Hilden, Germany). Digestion with restriction enzymes, electrophoretic separation on agarose gels, and transfer to nylon membranes (Boehringer, Mannheim, Germany) were performed using standard procedures (Sambrook et al. 1989). Membranes were hybridized at $65^{\circ} \mathrm{C}$ with the full-length NPT II marker probe PCR-labeled with digoxigenin-11-dUTP (Boehringer Mannheim), according to the manufacturer's protocols. After hybridization, membranes were washed under high stringency conditions and were detected using the DIG luminescent detection kit (Boehringer Mannheim).

Total RNA was isolated from tobacco leaves using the Qiagen Plant RNA Kit (Qiagen) and quantitated by spectrophotometry, assuming $\mathrm{A}_{260}=40 \mu \mathrm{g} / \mathrm{ml}$ (Sambrook et al. 1989). Total RNA $(15 \mu \mathrm{g})$ was electrophoresed through $1 \%$ agarose/formaldehyde gels and then transferred onto nylon membranes. Membranes were hybridized at $55^{\circ} \mathrm{C}$ overnight with hrap or hsr203J probes PCR-labeled with digoxigenin-11dUTP (Boehringer Mannheim), according to the manufacturer's protocols. After hybridization, membranes were washed under high stringency conditions and were detected using the DIG Luminescent detection kit (Boehringer Mannheim).
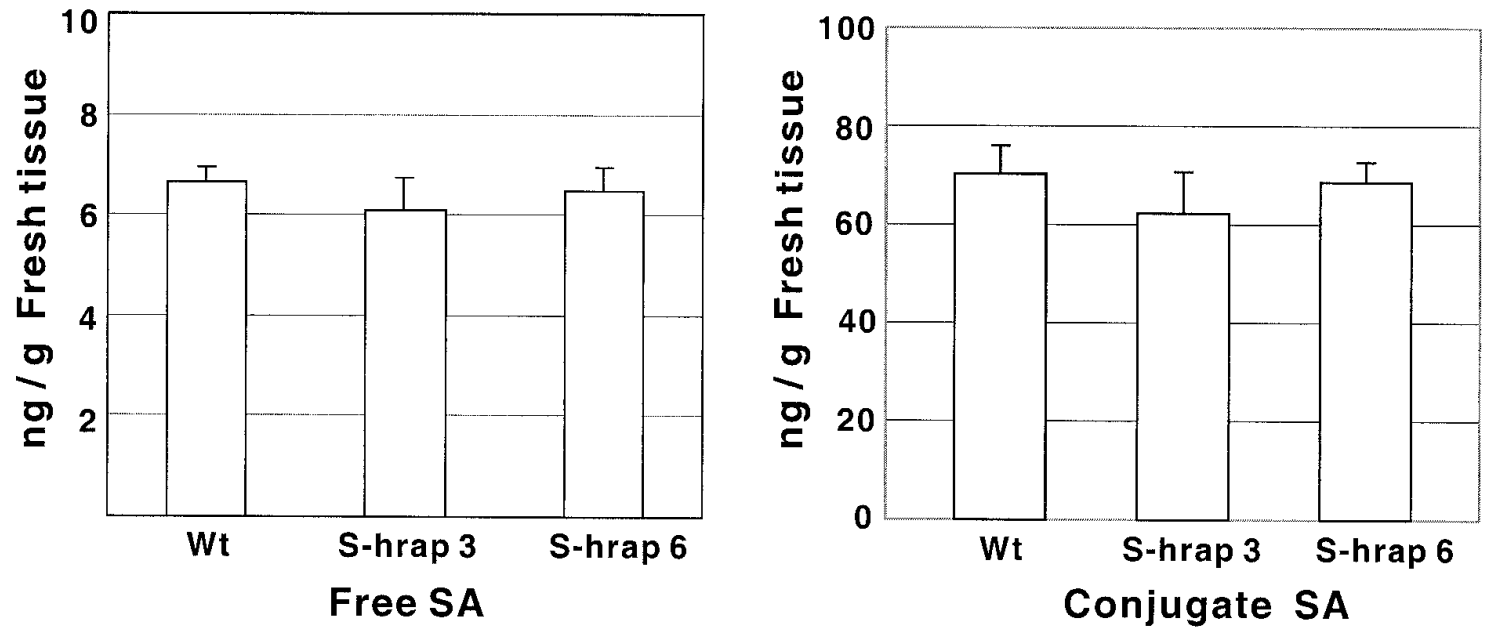

Fig. 6. Salicylic acid (SA) accumulation in wild-type and hrap transgenic tobacco plants. The basal levels of free and conjugate SA in control (Wt), Shrap3, and S-hrap6 transgenic tobacco were determined. Error bars indicate standard deviation of the mean using three individual plants for each line. 
Proteins were extracted by homogenizing $5 \mathrm{~g}$ of fresh leaf tissue in $5 \mathrm{ml}$ Tris buffer ( $50 \mathrm{mM}$ Tris, $\mathrm{pH} 7.5$ ) using a plastic pestle fitted to a $15 \mathrm{ml}$ centrifuge tube. The samples were precipitated with $60 \%$ ammonium sulfate and were dialyzed in $50 \mathrm{mM}$ Tris buffer. The protein concentrations of the samples were detected with Coomassie brilliant blue dye using a microassay method as recommended by the manufacturer (BioRad, Hercules, CA, U.S.A.). A sample $(20 \mu \mathrm{g})$ of each protein was electrophoresed through gel containing $12.5 \%$ polyacrylamide plus sodium dodecyl sulfate. These gels were then either stained with Coomassie blue or electro-transferred onto nitrocellulose membranes using the BioRad blue tank method. HRAP proteins were detected on Western blots using anti-HRAP antibodies followed with mouse anti-rabbit IgG-peroxidase conjugate.

\section{The expression and purification of HRAP in \\ Escherichia coli M15}

The expression and purification of HRAP in Escherichia coli M15 was carried out with a QIA expressionist kit (Qiagen). Recombinant HRAP was extracted by the native method for use in protein toxicity assays and pathogen resistance assays in vitro. The recombinant HRAP was purified with Ni-NTA agarose as recommended by the manufacturer (Qiagen).

\section{Recombinant HRAP antibacterial assay.}

$P$. syringae pv. tabaci was grown in nutrient broth at $30^{\circ} \mathrm{C}$ in the dark with overnight shaking. The bacterial suspension was diluted with water to $1.0 \times 10^{7} \mathrm{CFU} / \mathrm{ml}$ and mixed with $1 \mu \mathrm{M}$ of recombinant HRAP protein or BSA at room temperature for $15 \mathrm{~min}$. The mixtures were infiltrated into wild-type tobacco leaves and bacterial numbers were counted after inoculation.

\section{Harpin $_{P s s}$ preparation and plant HR assay.}

The harpin ${ }_{\text {Pss }}$ clone was provided by H.-C. Huang (Agricultural Biotechnology Laboratories, National Chung-Hsien University, Taiwan). Harpin ${ }_{\text {Pss }}$ protein was extracted by the methods described by $\mathrm{He}$ and associates (1993). Escherichia coli $\mathrm{DH} 5 \alpha$

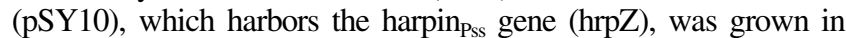
Luria broth containing ampicillin $(50 \mu \mathrm{g} / \mathrm{ml})$ at $37^{\circ} \mathrm{C}$ in the dark with shaking overnight in the presence of isopropylthio- $\beta$-Dgalactoside. To obtain harpin ${ }_{\mathrm{Pss}}$, the bacteria were first washed and sonicated for $30 \mathrm{~s}$ with $10 \mathrm{mM}$ phosphate buffer, $\mathrm{pH} 6.5$, and then boiled for $10 \mathrm{~min}$. After boiling, the extracts were centrifuged at $10,000 \times \mathrm{g}$ for $10 \mathrm{~min}$. Supernatants were desalted by a Microconcentrator (Amicon, Beverley, MA, U.S.A.) and stored at $4^{\circ} \mathrm{C}$.

The HR assay was performed according to Huang and associates (1988). Fully expanded tobacco leaves were wounded by a 25-gauge needle to form tiny holes on the lower surface of the leaves. Harpin ${ }_{\text {Pss }}$ were prepared in $50 \mathrm{mM}$ Tris buffer, $\mathrm{pH}$ 7.5 , and infiltrated by pressing a $1 \mathrm{ml}$ blunt syringe through the hole. The infiltrated plant was incubated in a growth chamber (16 h light and $8 \mathrm{~h}$ dark at $25^{\circ} \mathrm{C}$ ).

\section{Transgenic tobacco resistance assays.}

All transgenic tobacco resistance assays were carried out with T2 progenies of the transgenic plants in independent experiments. Fully expanded upper leaves of plants approximately 80 days old were used for infection with pathogen. Inoculations with Pseudomonas syringae pv. tabaci and Erwinia carotovora subsp. carotovora were performed as described by Li and associates (2000). Each inoculation was repeated six times in individual plants of each transgenic line. Bacteria inside the leaf discs were released by grinding the full infiltration area in sterile water in a microfuge tube and then plated on nutrient broth agar plates. In the E. carotovora subsp. carotovora treatments, the samples were cut from an area that extended $0.5 \mathrm{~cm}$ from the infiltration parts. The plates were cultured at $30^{\circ} \mathrm{C}$ overnight, and the colonies were counted the following day.

\section{Extraction and quantification of salicylic acid.}

Free and conjugate salicylic acid was extracted from tobacco leaves ( $0.5 \mathrm{~g}$ sample) and quantified by high-pressure liquid
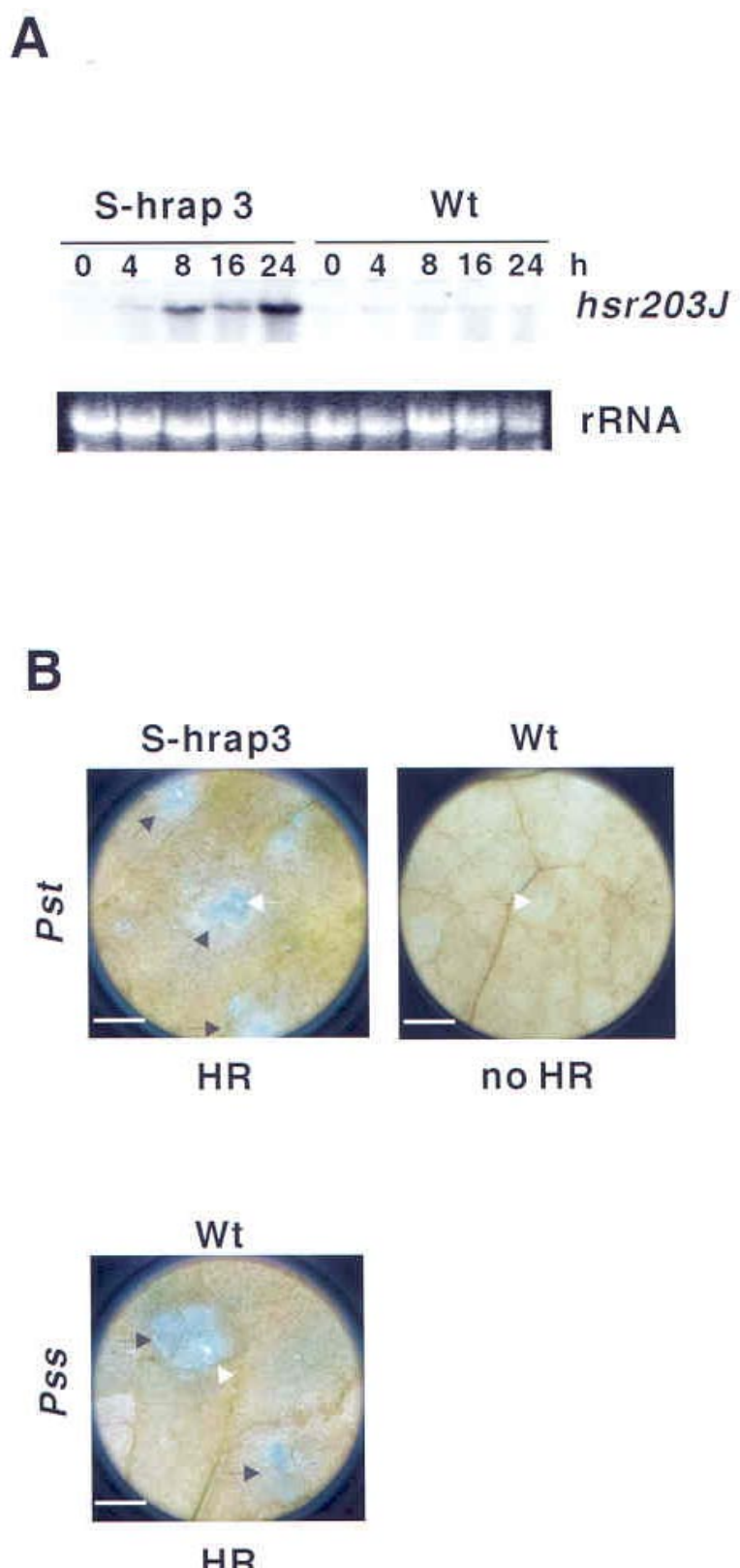

Fig. 7. Induction of $h s r 203 J$ gene expression and a micro-hypersensitive response (HR) in transgenic tobacco by a virulent pathogen infection. A, Induction of $h s r 203 \mathrm{~J}$ gene expression in transgenic tobacco by a virulent pathogen infection. The transgenic (S-hrap3) and wild-type (Wt) tobacco were infiltrated with $40 \mu \mathrm{l}$ of Pseudomonas syringae pv. tabaci $\left(1.0 \times 10^{7} \mathrm{CFU} / \mathrm{ml}\right)$. Total RNA in the infiltration areas of tobacco leaves was extracted at the timepoints indicated. RNA blots (15 $\mu \mathrm{g}$ per lane) were probed with the hsr203J cDNA probe. Ethidium bromide staining of rRNA was used to verify the loaded amount of total RNA. B. Induction of a micro-HR in transgenic tobacco by a virulent pathogen infection. The leaves of transgenic (S-hrap3) and control wild type (Wt) $24 \mathrm{~h}$ after inoculation with a virulent pathogen (P. syringae pv. tabaci, $1.0 \times 10^{6} \mathrm{CFU} / \mathrm{ml}$ ) were stained with trypan blue. To demonstrate the appearance of typical HR necrosis, a leaf of wild-type tobacco was inoculated with an avirulent pathogen $\left(P\right.$. syringae pv syringae, $\left.1.0 \times 10^{6} \mathrm{CFU} / \mathrm{ml}\right)$ and stained with dye $24 \mathrm{~h}$ after infection. This pathogen also induced a HR in transgenic tobacco (data not shown). White bar $=0.5 \mathrm{~cm}$. White arrows indicate the infiltration hole and black arrows clusters of dead (blue-stained) cells. 
chromatography with spectrofluorescence monitoring as described previously (Enyedi et al. 1992).

\section{Trypan blue-staining analysis.}

Dead plant cells were stained by collecting leaves and boiling them for $2 \mathrm{~min}$ in alcoholic lactophenol trypan blue $(20 \mathrm{ml}$ of ethanol, $10 \mathrm{ml}$ of liquid phenol, $10 \mathrm{ml}$ of lactic acid, $10 \mathrm{ml}$ of water, and $10 \mathrm{mg}$ of trypan blue). Stained leaves were rinsed in $50 \%$ ethanol and then rinsed in water. Individual leaves were photographed using an AGFA (ePhoto 1680) digital camera with microscopic lens.

\section{ACKNOWLEDGMENTS}

We would like to thank S.-C. Huang for providing the harpin ${ }_{\mathrm{Pss}}$ clone. Thanks are also due to D. Pontier for providing the hsr203J clone. This work was supported by grants to T.-Y. Feng from Academia Sinica, Taiwan, Republic of China.

\section{LITERATURE CITED}

Alfano, J. R., and Collmer, A. 1997. The type III (Hrp) secretion pathway of plant pathogenic bacteria: Trafficking harpins, Avr proteins, and death. J. Bacteriol. 179:5655-5662.

Bauer, D. W., Wei, Z.-M., Beer, S. V., and Collmer, A. 1995. Erwinia chrysanthemi harpin ${ }_{\mathrm{Ech}}$ : An elicitor of the hypersensitive response that contributes to soft-rot pathogenesis. Mol. Plant-Miocrobe Interact. 8:484-491.

Blaszczyk, A., Brodzik, R., and Sirko, A. 1999. Increased resistance to oxidative stress in transgenic tobacco plants overexpressing bacterial serine acetyltransferase. Plant J. 20:237-243.

Bogdanove, A. J., Beer, S. V., Bonas, U., Boucher, C. A., Collmer, A., Coplin, D. L., Cornelis, G. R., Huang, H. C., Hutcheson, S. W. Pavopoulos, N. J., and Van Gijsegem, F. 1996. Unified nomenclature for broadly conserved hrp genes of phytopathogenic bacteria. Mol. Microbiol. 20:681-683.

Bonas, U. 1994. Hrp genes of phytopathogenic bacteria. Pages 79-98 in: Current Topics in Microbiology and Immunology, Vol 192: Bacterial Pathogenesis of Plants and Animals: Molecular and Cellular Mechanisms, J. L. Dangle, ed. Springer-Verlag, Berlin.

Brown, I. R., Mansfield, J. W., Taira, S., Roine, E., and Romantschuk, M. 2001. Immunocytochemical localization of HrpA and HrpZ supports a role for the Hrp pilus in the transfer of effector proteins from Pseudomonas syringae pv. tomato across the host plant cell wall. Mol. PlantMicrobe Interact. 14:394-404.

Büschges, R., Hollricher, K., Panstruga, R., Simons, G., Wolter, M., Frijters, A., Van Daelen, R., Van der Lee, T., Diergaarde, P., Groenendijk, L., Toepsch, S., Vos, P., Salamini, F., and Schulze-Lefert, P. 1997. The barley Mlo gene: A novel control element of plant pathogen resistance. Cell 88:695-705.

Charkowski, A. O., Alfano, J. R., Preston, G., Yuan, J., He, S. Y., and Collmer, A. 1998. The Pseudomonas syringae pv. tomato HrpW protein has domains similar to harpins and pectate lyases and can elicit the plant hypersensitive response and bind to pectate. J. Bacterial 180: 5211-5217.

Chen, C. H., Lin, H. J., and Feng, T. Y. 1998. An amphipathic protein from sweet pepper can dissociate harpin ${ }_{\text {Pss }}$ multimeric forms and intensify the harpin ${ }_{\text {Pss }}-$ mediated hypersensitive response. Physiol. Mol. Plant. Path. 52:139-149.

Chen, C. H., Lin, H. J., Ger, M. J., Chow, D., and Feng, T. Y. 2000. cDNA cloning and characterization of a plant protein that may be associated with the harpin ${ }_{\mathrm{Pss}}-$ mediated hypersensitive response. Plant Mol. Biol 43:429-438.

Dangl, J. L. 1994. The enigmatic avirulence genes of phytopathogenic bacteria. Pages 99-118 in: Current Topics in Microbiology and Immunology, Vol 192: Bacterial Pathogensis of Plants and Animals-Molecular and Cellular Mechanisms. J. L. Dangl, ed. Springer-Verlag, Berlin.

Dangl, J. L., Dietrich, R. A. and Richberg, M. H. 1996. Death don't have no mercy: Cell death programs in plant-microbe interactions. Plant Cell 8:1793-1807.

Delaney, T. P., Uknes, S., Vernooij, B., Friedrich, L., Weymann, K., Negrotto, D., Graffney, T., Gut-Rella, M., Kessmann, H., Ward, E., and Ryals, J. 1994. A central role of salicylic acid in plant disease resistance. Science 266:1247-1250.

Desikan, R., Hancock, J. T., Coffey, M. J., and Neill, S. J. 1996. Generation of active oxygen in elicited cells of Arabidopsis thaliana is medi- ated by a NADPH oxidase-like enzyme. FEBS (Fed. Eur. Biochem. Soc.) Lett. 382:213-217.

Desikan, R., Clarke, A., Atherfold, P., Hancock, J. T., and Neill, S. J. 1999. Harpin induces mitogen-activated protein kinase activity during defence response in Arabidopsis thaliana suspension cultures. Planta 210:97-103.

Dietrich, R. A., Delaney, T. P., Uknes, S. J., Ward, E. R., Ryals, J. A., and Dangl, J. L. 1994. Arabidopsis mutants simulating disease resistance response. Cell 77:565-577

Dixon, R. A., and Lamb, C. J. 1990. Molecular communication in interactions between plants and microbial pathogens. Ann. Rev. Plant Physiol. Plant Mol. Biol. 41:339-367.

Enyedi, A. J., Yalpani, N., Silverman, P., and Raskin, I. 1992. Localization, conjugation, and function of salicylic acid in tobacco during the hypersensitive reaction to tobacco mosaic virus. Proc. Natl. Acad. Sci. U.S.A. 89:2480-2484.

Epple, P., Apel, K., and Bohlmann, H. 1997. Overexpression of an endogenous thionin enhances resistance of Arabidopsis against Fusarium oxysporum. Plant Cell 9:509-520.

Gaffney, T., Friedrich, L., Vernooij, B., Negrotto, D., Nye, G., Uknes, S., Ward, E., Kessmann, H., and Ryals, J. 1993. Requirement of salicylic acid for the induction of systemic acquired resistance. Science 261:754-756.

Galán, J. E., and Collmer, A. 1999. Type III secretion machines: Bacterial devices for protein delivery into host cells. Science 284:1322-1328.

Goodman, R. N. and Novacky, A. J. 1994. Pages 7-8 in: The hypersensitive reaction in plants to pathogens: A resistance phenomenon. American Phytopathological Society, St Paul, MN, U.S.A.

Grant, M. R. and Mansfield, J. W. 1999. Early events in host-pathogen interactions. Curr. Opin. Plant Biol. 2:312-319.

Greenberg, J. T., Guo, A., Klessig, D. F., and Ausubel, F. M. 1994. Programmed cell death in plants: A pathogen-triggered response activated coordinately with multiple defense functions. Cell 77:551-563.

Hahlbrock, K., and Scheel, D. 1989. Physiology and molecular biology of phenylpropanoid metabolism. Annu. Rev. Plant Physiol. Plant Mol Biol. 40:347-369.

He, S. Y., Huang, H. C., and Collmer, A. 1993. Pseudomonas syringae pv. syringae harpin ${ }_{\text {Pss }}$ : A protein that is secreted via the Hrp pathway and elicits the hypersensitive response in plants. Cell 73:1255-1266.

Holsters, M., De Waele, D., Depicker, A., Messens, E., Van Montagu, M., and Schell, J. 1978. Transfection and transformation of Agrobacterium tumefaciens. Mol. Gen. Genet. 163:182-187.

Horsch, R. B., Fry, J. E., Hofmann, N. L., Eichholtz, D., Rogers, S. G. Fraley, R. T. 1985. A simple and general method for transferring genes into plants. Science 227:1229-1231.

Huang, H. C., Schuurink, R., Denny, T. P., Atkinson, M. M., Baker, C. J., Yucel, I., Hutcheson, S. W., and Collmer, A. 1988. Molecular cloning of a Pseudomonas syringae pv. syringae gene cluster that enables Pseudomonas fluorescens to elicit the hypersensitive response in tobacco plants. J. Bact. 170:4748-4756.

Huang, H.-C., Lin, R.-H., Chang, C.-J., Collmer, A. and Deng, W.-L. 1995. The complete hrp gene cluster of Pseudomonas syringae pv. syringae 61 includes two blocks of gene required for harpin Pss $_{\text {secretion }}$ that are arranged collinearly with Yersinica ysc homologs. Mol. PlantMicrobe Interact. 8:733-746.

Keller, H., Pamboukdjian, N., Ponchet, M., Poupet, A., Delon, R., Verrier, J. L., Roby, D., and Ricci, P. 1999. Pathogen-induced elicitin production in transgenic tobacco generates a hypersensitive response and nonspecific disease resistance. Plant Cell 11:223-235.

Lamb, C. and Dixon, R. A. 1997. The oxidative burst in plant disease resistance. Annu. Rev. Plant Physiol. Plant Mol. Biol. 48:251-275.

Lee, J., Klüsener, B., Tsiamis, G., Stevens, C., Neyt, C., Tampakaki, A. P., Panopoulos, N. J., Nöller, J., Weiler, E. W., Cornelis, G. R., Mansfield, J. W., and Nürnberger, T. 2001. HrpZ $Z_{\text {Psph }}$ from the plant pathogen Pseudomonas syringae pv. phaseolicola binds to lipid bilayers and forms an ion-conducting pore in vitro. Proc. Natl. Acad. Sci. U.S.A. 98:289-294.

Li, Q., Von Lanken, C., Yang, L., Lawrence, C. B., and Hunt, A. G. 2000. The yeast polyadenylate-binding protein $(P A B 1)$ gene acts as a disease lesion mimic gene when expressed in plants. Plant Mol. Biol. 42:335344.

Malamy, J., Carr, J. P., Klessig, D. F., and Raskin, I. 1990. Salicylic acid: A likely endogenous signal in the resistance response of tobacco to viral infection. Science 250:1002-1004.

Mitsuhara, I., Matsufuru, H., Ohshima, M., Kaku, H., Nakajima, Y., Murai, N., Natori, S., and Ohashi, Y. 2000. Induced expression of sarcotoxin IA enhanced host resistance against both bacterial and fungal pathogens in transgenic tobacco. Mol. Plant-Microbe Interact. 13:860-868.

Morris, S. W., Vernooij, B., Titatarn, S., Starrett, M., Thomas, S., Wiltse, C. C., Frederiksen, R. A., Bhandhufalck, A., Hulbert, S., and Uknes, S 
1998. Induced resistance responses in maize. Mol. Plant-Microbe Interact. 11:643-658.

Penninckx, I. A. M. A., Eggermont, K., Terras, F. R. G., Thomma, B. P. H. J., De Samblanx G. W., Buchala, A., Metraux, J. P., Manners, J. M., and Broekaert, W. F. 1996. Pathogen-induced systemic activation of a plant defensin gene in Arabidopsis follows a salicylic acid-independent pathway. Plant Cell 8:2309-2323.

Pontier, D., Godiard, L., Marco, Y., and Roby, D. 1994. hsr203J, a tobacco gene whose activation is rapid, highly localized and specific for incompatible plant/pathogen interactions. Plant J. 5:507-521.

Pontier, D., Balagué, C., Bezombes-Marion, I., Tronchet, M., Deslandes, L., and Roby, D. 2001. Identification of a novel pathogen-responsive element in the promoter of the tobacco gene HSR203J, a molecular marker of the hypersensitive response. Plant J. 26:495-507.

Rao, A. G. 1995. Antimicrobial peptides. Mol. Plant-Microbe Interact 8:6-13.

Sambrook, J., Fritsch, E. F., and Maniatis, T. 1989. Pages 9.31-9.57, E6 in: Molecular Cloning: A Laboratory Manual, 2nd ed., Cold Spring Harbor Laboratory Press, Cold Spring Harbor, NY, U.S.A.

Shen, S., Li, Q., He, S. Y., Barker, K. R., Li, D., and Hunt, A. G. 2000. Conversion of compatible plant-pathogen interactions into incompatible interactions by expression of the Pseudomonas syringae pv. syringae $61 \mathrm{hrmA}$ gene in transgenic tobacco plants. Plant J. 23:205-213.

Sutherland M. W. 1991. The generation of oxygen radicals during host plant responses to infection. Physiol. Mol. Plant Pathol. 39:79-93.

Tampakaki, A. P., and Panopoulos, N. J. 2000. Elicitation of hypersensi- tive cell death by extracellularly targeted $\mathrm{HrpZ}_{\mathrm{Psph}}$ produced in planta. Mol. Plant-Microbe Interact. 13:1366-1374.

Terras, F. R. G., Eggermont, K., Kovaleva, V., Raikhel, N. V., Osborn, R. W., Kester, A., Rees, S. B., Torrekens, S., Van Leuven, F., and Vanderleyden, J. 1995. Small cysteine-rich antifungal proteins from radish: The role in host defense. Plant Cell 7:573-588.

Tsiamis, G., Mansfield, J. W., Hockenhull, R., Jackson, R. W., Sesma, A., Athanassopoulos, E., Bennett, M., Stevens, C., Vivian, A., Taylor, J. D., and Murillo, J. 2000. Cultivar-specific avirulence and virulence functions assigned to avrPphF in Pseudomonas syringae pv. phaseolicola, the cause of bean halo-blight disease. EMBO (Eur. Mol. Biol. Organ.) J. 13:3204-3214.

Van Gijsegem, F., Genin, S., and Boucher, C. 1993. Evolutionary conservation of pathogenicity determinants among plant and animal pathogenic bacteria. Trends Microbiol. 1:175-180.

Van Loon, L. C. 1999. Occurrence and properties of plant pathogenesisrelated protein. Pages 1-20 in: Pathogenesis-Related Proteins in Plants. S. K. Datta and S. Muthukrishnan, eds. CRC Press, New York.

Verberne, M. C., Verpoorte, R., Bol, J. F., Mercado-Blanco, J., and Linthorst, H. J. M. 2000. Overproduction of salicylic acid in plants by bacterial transgenes enhances pathogen resistance. Nature Biotech 18:779-783.

Wei, Z. M., Laby, R. J., Zumoff, C. H., Bauer, D. W., He, S. Y., Collmer, A., and Beer, S. V. 1992. Harpin, elicitor of the hypersensitive response produced by the plant pathogen Erwinia amylovora. Science 257:85-88. 